\title{
Financial Crises and Nexus Between Economic Growth and Foreign Direct Investment
}

\section{Debesh Bhowmik}

Dr., Retired Principal and Associated with International Institute for Development Studies, Kolkata, Life member, Indian Economic Association, The Indian Econometric Society, Bengal Economic Association, Associate Editor-Arthabeekshan-The Journal of BengalEconomic Association Residence, India.

\begin{abstract}
In this paper, author tried to find relation of foreign direct investment inflows with its determinants like growth rate, interest rate, exchange rate, inflation rate, fiscal deficit, openness in India during 1971-2015 through causality, co-integration and vector error correction models. In this paper, it was attempted to explain clearly that how foreign direct investment inflows and outflows have changed during several financial crises in different regions of the world since 1970s in support with a historical analysis over global financial crises. The paper concludes that FDI inflows in India has been catapulting at the rate of $21.56 \%$ per year during 1971 2015 and exponentially at the rate of $0.6044 \%$ per year significantly. It has four upward structural breaks in 1985, 1994, 2000 and 2006 respectively during the specified period. FDI inflows in India has causal relation uni-directionally with fiscal deficit, and bi-directionally with inflation, exchange rate, interest rate and growth rate during 1971-2015.Johansen co-integration test confirmed that Trace Statistic contains four co-integrating equations and Max Eigen Statistic has three co-integrating equations. VECM is stable, non-stationary and not good fit for four estimated equations and error corrections for the equations of change of interest rate and inflation rate showed significant with speeds of $23 \%$ and $103 \%$ per year. The paper also concludes that FDI does not cause Granger financial crises, but financial crises do cause Granger FDI.
\end{abstract}

Keywords: Foreign Direct Investment, economic growth, financial crises, co-integration, vector error correction.

JEL Classification: C23, C33, F21, F01, O55.

(C) The Author, 2018. This article is published with open access at Sumy State University.

\section{Introduction}

Foreign Direct Investment has several dimensions. It affects host countries' balance of payments and development process. It has long run effects on economic growth and sustainable development which depend on the character of FDI. However, the nexus between growth and FDI is indeterminate since it varies from region to region, country to country and from period to period although the globalization, liberalization and privatization drives accelerated the speed of the nexus towards positive direction irrespective of the distribution of income. Historically, FDI changes from merchants' capital to multinational investments, from imperialistic attitude to trade domination through economic integration (via financial integration) in international trade and finance.

FDI does not cause crises directly, but it has indirect causes of bubbles and busts. Debt finance through FDI may stimulate debt burden under recession. Financial and banking crises may emerge if FDI in banking sector find losses and shut downs. Yet we cannot avoid the fact that FDI does not Granger cause of financial crises but financial crises do Granger cause FDI changes which were observed in all the financial crises in the world.

Since the Baring crisis in 1870, India's FDI was dominated by British imperialism through East India Company whose chief competitors were Dutch East India Company, Danish East India Company, Portuguese East India Company, French East India Company and Swedish East India Company respectively. In 1913, India's foreign investment stood 35\% of GDP and per capita foreign investment was 6 dollar at 1900 US dollar and foreign direct investment as percent of domestic capital stock was 9\%.Presently,India's FDI inflows is very low in comparison to other countries ,e.g. in 2017 , India's FDI was accounted as $1.9 \%$ of GDP and government of India expects it to rise to $2.5 \%$ of GDP with in next five years. In 2017, Mauritius was the top donor country to India comprising 11.47 billion US Dollar followed by Singapore 5.29 billion US Dollar, Netherlands 1.95 billion US Dollar, USA 1.33 billion US Dollar and Germany 934 million US Dollar respectively. As on 2017, Service sector is leading the sectoral distribution of FDI i.e. 8.68 billion US Dollar followed by telecommunication 5.56 billion US Dollar, Computer hardware and software 3.65 billion US Dollar, Trading 
2.34 billion US Dollar, Automobile 1.61 billion US Dollar, and Metallurgical industry 1.44 billion US Dollar respectively. During the era of globalization and liberalization, India is following $100 \%$ liberalization in FDI inflows in several sectors of the economy. India is not the exceptional country from where global financial crises did not enter and affect negatively like other developed and developing countries. Foreign direct investment flows also affected due to financial crises in Indian economy which is a great content of research in relating to other macro fundamentals.

On this overview, author tried to verify nexus between FDI inflows and growth in Indian economy using econometric analysis and studied analytically the changes of FDI flows during crises.

\section{Literature review}

The nexus between Growth and FDI inflows varies from country to country, from one period to another and from one sector to other in which there are many economic literatures that represent economic relevance. Chakraborty \& Basu (2002) suggest that GDP in India is not Granger caused by FDI, the causality seems to run more from GDP to FDI. Li \&Liu (2005) studied 84 countries using data of 1970-1999 periods and concluded that a $10 \%$ increase in FDI can stipulate 4.1\% growth rate per year. Johnson (2006) took 90 developed and developing countries using data of 1980-2002 period and concluded positive relation through OLS method. Hansen \& Rand (2006) used co-integration and causality tests in 31 developing countries during 1970-2000 and showed positive relation. Herzer et.al (2008) verified the nexus in 28 developing countries during 1970-2003 and found positive nexus. Applying vector error correction model, Dinda (2009) empirically investigated the determinants of foreign direct investment inflows to Nigeria during 1970-2006. This study suggests that the endowment of natural resources, openness, macroeconomic risk factors like inflation and exchange rates are significant determinants of FDI inflows to Nigeria. Stehrer \& Woerz (2009) verified the relation in OECD and non OECD countries during 1981-2000 and found that a 10\% increase in FDI can increase $1.2 \%$ in growth rate per year. Ewing \& Yang (2009) studied 48 states in USA during 1977-2001 in manufacturing sector and found direct relation between growth and FDI. Nair (2010) showed that FDI has a positive and highly significant effect on overall growth in India during 1970-2000 in regression results which leads to an increase in market size. The result proves that it cannot be rejected that the FDI does not Granger cause GDP growth at the 5\% level, but it can be reflected that GDP growth does not Granger cause FDI. N'guessan \& Yue (2010) concluded that there is a long run relationship between FDI, trade openness and growth which stated that about $10 \%$ increase in trade openness would lead to about $97 \%$ growth of output and $10 \%$ increase in FDI would result in about $1 \%$ in growth of output. The UNCTAD study which covers 140 countries over the period 1998-2000 with 8 explanatory variables show that FDI can be explained in terms of GDP per capita, exports as a percentage of GDP and telephone lines per 1000 of the populations. In general terms the results tell us that countries that are more successful in attracting FDI are developed countries with a high degree of openness. Factors failing the EBA robustness test as determinants of FDI inflows included: GDP growth rate, commercial energy use, R\&D expenditure, tertiary enrolments and country risk. Tiwari \& Mihari (2011) verified that exports and FDI show a significant and positive impact on economic growth in a panel of 23 Asian countries during 1986-2008. Adeniyi, Omisakin, Egwaikhide \& Oyinlola (2012) showed that FDI has positive linkage over economic growth in five ECOWAS countries during 1970-2005 which was verified through Granger causality tests in VEC model. Yesuf \& Tsehaye (2012) investigated the causal link between FDI and economic growth in Ethiopia during 1974-2010 and did not find any causality running from FDI to growth or vice versa but there was an evidence of co-integration between FDI and growth. The flow of FDI is too small to translate into growth. Using the VAR Granger causality/ Block Exogeneity Wald Test in Cote d'Ivoire during 1980-2007, Anyanwu (2012) estimated from cross-country regressions for the period 1996-2008 which indicate that: (i) there is a positive relationship between market size and FDI inflows; (ii) openness to trade has a positive impact on FDI inflows; (iii) higher financial development has negative effect on FDI inflows; (iv) the prevalence of the rule of law increases FDI inflows; (v) higher FDI goes where foreign aid also goes; (vi) agglomeration has a strong positive impact on FDI inflows; (vi) natural resource endowment and exploitation (such as oil) attracts huge FDI; (vii) East and Southern African sub-regions appear positively disposed to obtain higher levels of inward FDI. Tintin (2012) showed that FDI spurs economic growth and development in developed, developing and the least developed countries which was found from the study of a sample of 125 countries (38 developed, 58 developing and 29 least developed countries) over the 1980-2010 period by using least square method of the panel data. Ragimana (2012) studied that FDI growth nexus was positive in Solomon Island during 1970-2010 which was verified through Granger Causality test and Cointegration test. Adelake (2014) found that FDI had positive overall effect on economic growth in Sub-Saharan 
Africa, although the magnitude of this effect depends on some country specific features during 1996-2010 of 31 SSA countries of panel data where role of governance should positive on encouraging FDI inflows.

\section{Objective of the paper}

In this paper, author tried to find relation of foreign direct investment inflows with macro determinants like growth rate, interest rate, exchange rate, inflation rate, fiscal deficit, openness in India during 1971-2015 through causality, co-integration and vector error correction models along with other residual tests. Even, author found out the trends and structural shifts of foreign direct investment inflows in India during the same period. In this paper, it was attempted to explain clearly that how foreign direct investment inflows and outflows have changed during several financial crises in different regions of the world since 1970s in support with a historical analysis over global financial crises. In this context, the limitations of the paper, future scope of research and some policy prescriptions have been placed for forthcoming discussions.

\section{Methodology and data}

Assume, $\mathrm{x}_{1}=\mathrm{GDP}$ growth rate per cent per year, $\mathrm{x}_{2}=$ interest rate per cent per year(discount rate), $\mathrm{x}_{3}=$ exchange rate of rupee per US dollar, $\mathrm{x}_{4}=$ inflation rate(per cent change of $\left.\mathrm{CPI}\right), \mathrm{x}_{5}=$ fiscal deficit per cent of GDP, $\mathrm{x}_{6}=$ external debt per cent of GDP, $\mathrm{x}_{7}=$ trade openness per cent, $\mathrm{y}=$ FDI inflows in India in million US dollar. Data have been collected from the World Bank, and International Financial Statistics of IMF from 1971 to 2015.Semi-log and exponential regression models were applied to calculate trends. Granger (1969) model was applied to test causality. Bai-Perron model (2003) was applied to find structural breaks of the foreign direct investment inflows in India. For co-integration test and vector error correction analysis we used Johansen $(1988,1996)$ methodologies. We used Hansen-Doornik (1994) test for normality.

\section{Economic growth-foreign direct investment nexus: A Case Study of India. Observations from the Econometric models}

India's FDI inflows have been increasing at the $21.56 \%$ per year during $1971-2015$ which is significant at 5\% level.

$\log (\mathrm{y})=1.4485+0.215672 \mathrm{t}$

$(4.11)^{*}(16.16)^{*}$

$\mathrm{R}^{2}=0.858, \mathrm{~F}=261.37^{*}, \mathrm{DW}=1.53,{ }^{*}=$ significant at $5 \%$ level, $\mathrm{y}=\mathrm{FDI}$ inflows in million dollars. $\mathrm{t}=$ =ear (time).

In Figure 1, the actual and fitted trend lines have been plotted. The fitted line is steeply rising upward.

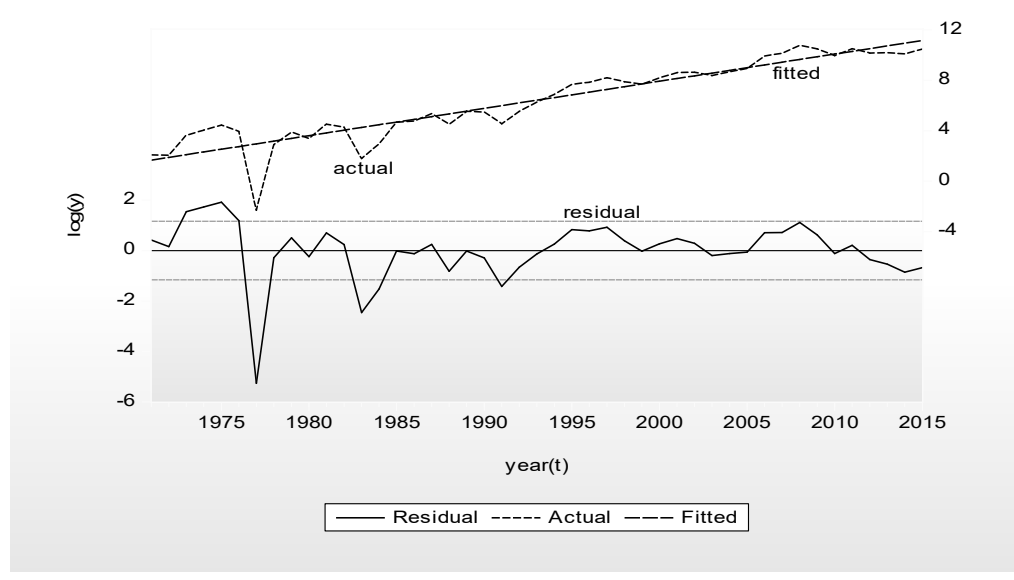

Figure 1. Trend line of FDI inflows

Source-Plotted by author

The exponential fitted trend line of Indian FDI inflows during 1971-2015 is also significant and it is exponentially rising at the rate $0.6044 \%$ per year.

$\mathrm{y}=e^{0.6651+{ }^{0.604473+u t},}$

where $\mathrm{U}_{\mathrm{t}}=-0.117016 \mathrm{U}_{\mathrm{t}-1}$ 
$\mathrm{R}^{2}=0.828, \mathrm{DW}=2.13$, Inverted $\mathrm{AR}$ root $=0.50 \pm 0.30 \mathrm{i}$ and -0.34 , the $\mathrm{t}$ values of 0.6651 and 0.604473 are 5.064583 and 112.5020 respectively which are significant at $5 \%$ level. The estimated exponential trend line and actual line are shown in Figure 2.

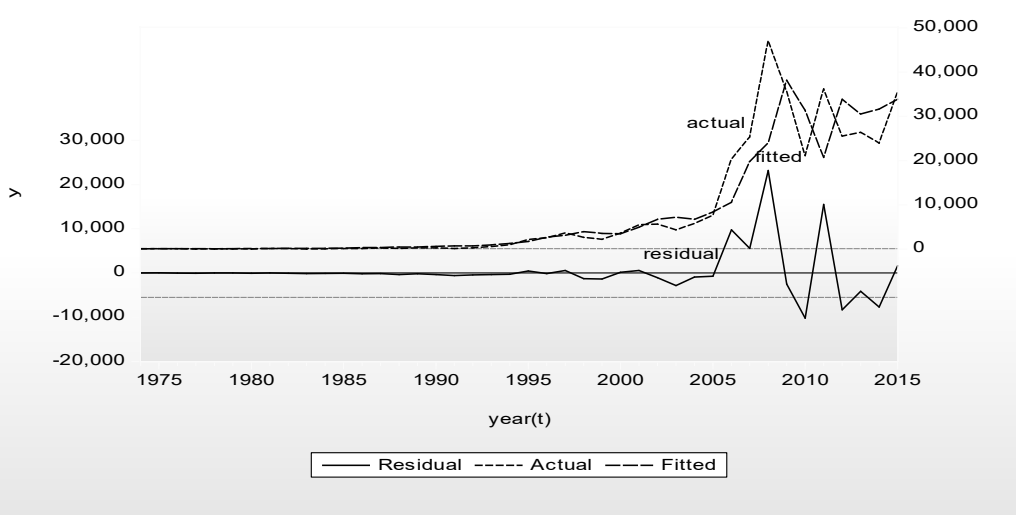

Figure 2. Exponential trend of FDI inflows

Source-Plotted by author

Applying Bai-Perron test (2003) of L+1 vs. L sequential determined breaks selecting Trimming 0.15, maximum breaks 5 with 5\% significant level, we found four upward structural breaks in 1985, 1994, 2000, 2006 respectively following HAC standard errors and covariance and Newey-West fixed band width=4.0. In Table 1, the significant values are given.

Table 1. Structural breaks

\begin{tabular}{|c|c|c|c|c|}
\hline Variable & Coefficient & Std. Error & t-Statistic & Prob. \\
\hline & & $1971-1984--14$ obs & & \\
\hline \multirow[t]{2}{*}{$\mathrm{C}$} & 2.968555 & 0.483099 & 6.144817 & 0.0000 \\
\hline & & $1985-1993--9$ obs & & \\
\hline \multirow[t]{2}{*}{$\mathrm{C}$} & 5.184334 & 0.198430 & 26.12671 & 0.0000 \\
\hline & & $1994-1999-6$ obs & & \\
\hline \multirow[t]{2}{*}{$\mathrm{C}$} & 7.690081 & 0.173512 & 44.32012 & 0.0000 \\
\hline & & $2000-2005-6$ obs & & \\
\hline \multirow[t]{2}{*}{$\mathrm{C}$} & 8.566927 & 0.102723 & 83.39861 & 0.0000 \\
\hline & & $2006-2015-10$ obs & & \\
\hline \multirow[t]{2}{*}{$\mathrm{C}$} & 10.26461 & 0.087104 & 117.8438 & 0.0000 \\
\hline & & $\mathrm{R}^{2}=0.889, \mathrm{~F}=80.4^{*}, \mathrm{DW}=1.99$ & & \\
\hline \multicolumn{5}{|c|}{ Break test: Sequential F-statistic determined breaks: 4} \\
\hline Break Test & F-statistic & Scaled F-statistic & Critical Value** & \\
\hline 0 vs. $1 *$ & 136.9461 & 136.9461 & 8.58 & \\
\hline 1 vs. $2 *$ & 133.9357 & 133.9357 & 10.13 & \\
\hline 2 vs. $3 *$ & 19.38291 & 19.38291 & 11.14 & \\
\hline 3 vs. $4 *$ & 18.00003 & 18.00003 & 11.83 & \\
\hline 4 vs. 5 & 0.999666 & 0.999666 & 12.25 & \\
\hline
\end{tabular}

Source: Computed by author, ${ }^{*}=$ significant at $5 \%$ level.

In Figure 3, the successive four upward breaks have been plotted in the fitted line showing actual line and residual lines of FDI inflows in terms of log. 


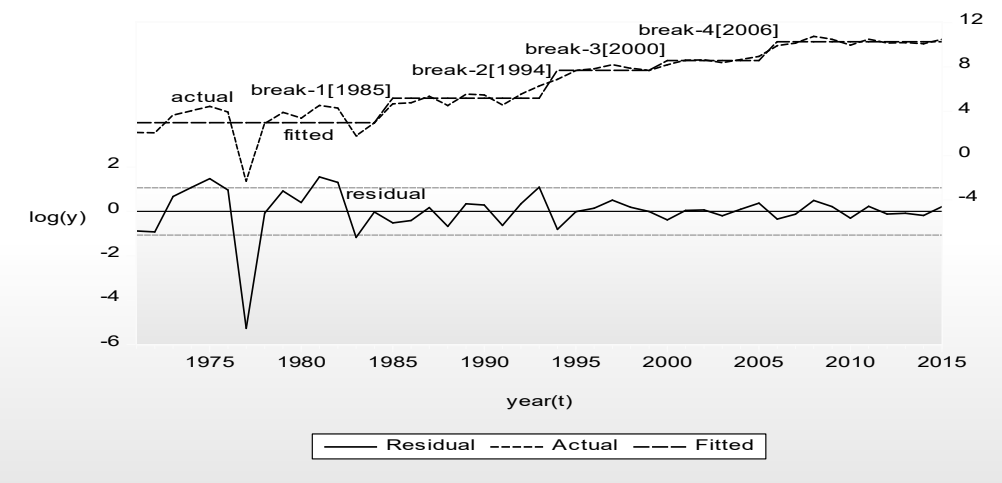

Figure 3. Structural breaks in FDI inflows

Source: Plotted by author.

Granger causality test assured that there are no causality between FDI $\left(\mathrm{y}_{1}\right)$ and openness $\left(\mathrm{x}_{7}\right)$, but there exists uni-directional causality between FDI and fiscal deficit ( $\left.\mathrm{x}_{5}\right)$, and there are bi-directional causality among FDI and inflation $\left(\mathrm{x}_{4}\right)$,FDI and exchange rate $\left(\mathrm{x}_{3}\right)$ and FDI and interest rate $\left(\mathrm{x}_{2}\right)$, FDI inflows and growth rate $\left(\mathrm{x}_{1}\right)$ respectively during 1971-2015.In Table-2, the results of Granger causality test are given. This observation is similar to the studies of Sarbapriya Ray (2012).

Table 2. Granger causality test

\begin{tabular}{|c|c|c|c|}
\hline $\begin{array}{r}\text { Null Hypothesis: } \\
\end{array}$ & Obs & F-Statistic & Prob. \\
\hline Y does not Granger Cause $\mathrm{X}_{1}$ & 44 & 3.76020 & 0.0594 \\
\hline $\mathrm{X}_{1}$ does not Granger Cause $\mathrm{Y}$ & & 2.65379 & 0.1110 \\
\hline $\mathrm{Y}$ does not Granger Cause $\mathrm{X}_{2}$ & 44 & 0.06276 & 0.8034 \\
\hline $\mathrm{X}_{2}$ does not Granger Cause $\mathrm{Y}$ & & 3.24339 & 0.0791 \\
\hline $\mathrm{Y}$ does not Granger Cause $\mathrm{X}_{3}$ & 44 & 0.27972 & 0.5997 \\
\hline $\mathrm{X}_{3}$ does not Granger Cause $\mathrm{Y}$ & & 3.35859 & 0.0741 \\
\hline $\mathrm{Y}$ does not Granger Cause $\mathrm{X}_{4}$ & 44 & 0.10544 & 0.7470 \\
\hline $\mathrm{X}_{4}$ does not Granger Cause $\mathrm{Y}$ & & 1.27829 & 0.2648 \\
\hline $\mathrm{Y}$ does not Granger Cause $\mathrm{X}_{5}$ & 44 & 9.75678 & 0.0033 \\
\hline $\mathrm{X}_{5}$ does not Granger Cause $\mathrm{Y}$ & & 0.00764 & 0.9308 \\
\hline Y does not Granger Cause $\mathrm{X}_{6}$ & 44 & 0.53797 & 0.4674 \\
\hline $\mathrm{X}_{6}$ does not Granger Cause $\mathrm{Y}$ & & 0.07397 & 0.7870 \\
\hline $\mathrm{Y}$ does not Granger Cause $\mathrm{X}_{7}$ & 44 & 6.74823 & 0.0130 \\
\hline $\mathrm{X}_{7}$ does not Granger Cause $\mathrm{Y}$ & & 14.6940 & 0.0004 \\
\hline
\end{tabular}

Source: Computed by author.

Johansen unrestricted co-integration rank test showed that Trace statistic has four co-integrating equations and Max Eigen Statistic has three co-integrating equations which are shown in Table 3. Therefore the variables are co-integrated in order of CI (1). According to Trace statistic, there must be three linear combinations and according to Max Eigen statistic there must be two linear combinations. This result is more or less similar to researches of Basu, Chakraborty \& Reagle (2003), Saji (2013) and Chakraborty \& Basu (2010).

Table 3. Johansen Co-integration test

\begin{tabular}{|c|c|c|c|c|}
\hline Hypothesized No. of CE(s) & Eigen value & Trace Statistic & 0.05 Critical Value & Prob.** \\
\hline None * & 0.732982 & 219.9294 & 159.5297 & 0.0000 \\
\hline At most $1 *$ & 0.659855 & 163.1505 & 125.6154 & 0.0000 \\
\hline At most $2 *$ & 0.612689 & 116.7800 & 95.75366 & 0.0008 \\
\hline At most $3 *$ & 0.495951 & 75.99326 & 69.81889 & 0.0148 \\
\hline At most 4 & 0.348309 & 46.53476 & 47.85613 & 0.0662 \\
\hline At most 5 & 0.309576 & 28.12279 & 29.79707 & 0.0770 \\
\hline At most 6 & 0.240770 & 12.19346 & 15.49471 & 0.1479 \\
\hline At most 7 & 0.008086 & 0.349106 & 3.841466 & 0.5546 \\
\hline Hypothesized No. of CE(s) & Eigen value & Max Eigen Statistic & 0.05 Critical Value & Prob.** \\
\hline None $*$ & 0.732982 & 56.77893 & 52.36261 & 0.0166 \\
\hline At most $1 *$ & 0.659855 & 46.37050 & 46.23142 & 0.0483 \\
\hline At most $2 *$ & 0.612689 & 40.78672 & 40.07757 & 0.0415 \\
\hline At most 3 & 0.495951 & 29.45849 & 33.87687 & 0.1540 \\
\hline At most 4 & 0.348309 & 18.41197 & 27.58434 & 0.4612 \\
\hline At most 5 & 0.309576 & 15.92934 & 21.13162 & 0.2290 \\
\hline
\end{tabular}


Table 3 (cont.). Johansen Co-integration test

\begin{tabular}{|l|l|l|l|l|}
\hline At most 6 & 0.240770 & 11.84435 & 14.26460 & 0.1166 \\
\hline At most 7 & 0.008086 & 0.349106 & 3.841466 & 0.5546 \\
\hline
\end{tabular}

Notes: * denotes rejection of the hypothesis at the 0.05 level, **MacKinnon-Haug-Michelis (1999) p-values, H0=No co-integration, Source-Computed by author.

Since the variables are co-integrated, then the estimated vector error correction model is given below. The study of VECM was also tested by Dash \& Parida (2013) and Ray (2012) in India.

[1] $\Delta \mathrm{x}_{1 \mathrm{t}}=-0.024378-0.46107 \Delta \mathrm{x}_{1 \mathrm{t}-1}-0.0624 \Delta \mathrm{x}_{2 \mathrm{t}-1}+0.2556 \Delta \mathrm{x}_{3 \mathrm{t}-1}+0.1718 \Delta \mathrm{x}_{4 \mathrm{t}-1}+0.3480 \Delta \mathrm{x}_{5 \mathrm{t}-1}$
$(-0.043)$
$(-2.75)^{*}$
$(-0.089)$
(1.048)
(1.94)
$(0.78)$

$-0.28909 \Delta \mathrm{x}_{6 \mathrm{t}-1}-0.0729 \Delta \mathrm{x}_{7 \mathrm{t}-1}+2.28 \mathrm{E}-05 \Delta \mathrm{y}_{\mathrm{t}-1}-0.2381 \mathrm{EC}$
$(-0.714)$
$(-0.29) \quad(-1.02)$
$(-1.02)$

$\mathrm{R}^{2}=0.48, \mathrm{~F}=3.4, \mathrm{AIC}=5.14, \mathrm{SC}=5.55,{ }^{*}=$ significant at $5 \%$ level,$\Delta \mathrm{x}_{1 \mathrm{t}}$ and $\Delta \mathrm{x}_{1 \mathrm{t}-1}$ are negatively related significantly.

[2] $\Delta \mathrm{x}_{2 \mathrm{t}}=-0.0924+0.1129 \Delta \mathrm{x}_{1 \mathrm{t}-1}-0.2025 \Delta \mathrm{x}_{2 \mathrm{t}-1}+0.0076 \Delta \mathrm{x}_{3 \mathrm{t}-1}+0.0068 \Delta \mathrm{x}_{4 \mathrm{t}-1}+0.0207 \Delta \mathrm{x}_{5 \mathrm{t}-1}$
$(-0.72) \quad(2.88)^{*}$
$(-1.27)$
$(0.137)$
$(0.337)$
$(0.203)$

$-0.0855 \Delta \mathrm{x}_{6 \mathrm{t}-1}+0.0303 \Delta \mathrm{x}_{7 \mathrm{t}-1}+3.02 \mathrm{E}-05 \Delta \mathrm{y}_{\mathrm{t}-1}-0.23196 \mathrm{EC}$
$(-0.92)$
$(0.529)$
(1.129)
$(-4.33)^{*}$

$\mathrm{R}^{2}=0.49, \mathrm{~F}=3.6, \mathrm{AIC}=2.19, \mathrm{SC}=2.6,{ }^{*}=$ significant, $\Delta \mathrm{x}_{2 \mathrm{t}}$ and $\Delta \mathrm{x}_{1 \mathrm{t}-1}$ are positively related significantly.

[3] $\Delta \mathrm{x}_{3 \mathrm{t}}==1.3603+-0.00155 \Delta \mathrm{x}_{1 \mathrm{t}-1}+0.711074 \Delta \mathrm{x}_{2 \mathrm{t}-1}+0.2534 \Delta \mathrm{x}_{3 \mathrm{t}-1}-0.05331 \Delta \mathrm{x}_{4 \mathrm{t}-1}-0.762132 \Delta \mathrm{x}_{5 \mathrm{t}-1}$
$(2.92) *(-0.011)$
(1.23)
$(1.25)$
$(-0.72)$
$(2.06)^{*}$

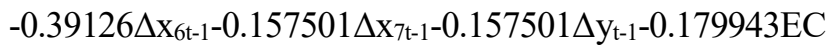
$(-1.16)$
$(-0.76)$
$(-0.51)$
$(-0.92)$

$\mathrm{R}^{2}=0.19, \mathrm{~F}=0.87, \mathrm{AIC}=4.7, \mathrm{SC}=5.1,{ }^{*}=$ significant,$\Delta \mathrm{x}_{3}$ and $\Delta \mathrm{x}_{5 \mathrm{t}-1}$ are negatively related significantly.

[4] $\Delta \mathrm{x}_{4 \mathrm{t}}=0.388400-0.007038 \Delta \mathrm{x}_{1 \mathrm{tt}-1}-0.907988 \Delta \mathrm{x}_{2 \mathrm{t}-1}+0.079949 \Delta \mathrm{x}_{3 \mathrm{t}-1}-0.246616 \Delta \mathrm{x}_{4 \mathrm{t}-1}{ }^{-}$
$(2.92)^{*} \quad(-0.082)$
$(0.68)$
$(0.17)$
$(-1.47)$

$0.097889 \Delta \mathrm{x}_{5 \mathrm{t}-1}-0.952970 \Delta \mathrm{x}_{6 \mathrm{t}-1}-0.442524 \Delta \mathrm{x}_{7 \mathrm{t}-1}+0.000244 \Delta \mathrm{y}_{\mathrm{t}-1-1}-1.025525 \mathrm{EC}$
$(-0.115)$
$(-1.24)$
$(-0.93)$
(1.10)
$(-2.31)^{*}$

$\mathrm{R}^{2}=0.26, \mathrm{~F}=1.33, \mathrm{AIC}=6.42, \mathrm{SC}=6.83,{ }^{*}=$ significant

[5] $\Delta \mathrm{x}_{5 \mathrm{t}}=-0.106383+0.007038 \Delta \mathrm{x}_{1 \mathrm{t}-1}+-0.071309 \Delta \mathrm{x}_{2 \mathrm{t}-1}+0.109699 \Delta \mathrm{x}_{3 \mathrm{t}-1}+0.013372 \Delta \mathrm{x}_{4 \mathrm{t}-1}$
$(-0.49)$
(0.109)
$(-0.26)$
(1.17)
$(0.17)$

$+0.158234 \Delta \mathrm{x}_{5 \mathrm{t}-1}-0.053390 \Delta \mathrm{x}_{6 \mathrm{t}-1}-0.016278 \Delta \mathrm{x}_{7 \mathrm{t}-1}+0.000125 \Delta \mathrm{y}_{\mathrm{t}-1-0.004321 \mathrm{EC}}$
(0.92)
$(-0.34)$
$(-0.17)$
$(2.8)^{*}$
$(-0.04)$

$\mathrm{R}^{2}=0.33, \mathrm{~F}=1.86, \mathrm{AIC}=3.22, \mathrm{SC}=3.68,{ }^{*}=$ significant, $\Delta \mathrm{x}_{5 \mathrm{t}}$ and $\Delta \mathrm{y}_{\mathrm{t}-1}$ are positively related significantly.

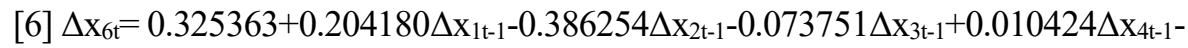
(0.87)
$(1.83)$
$(-0.83)$
$(-0.073)$
$(0.17)$

$0.134339 \Delta \mathrm{x}_{5 \mathrm{t}-1}+0.175616 \Delta \mathrm{x}_{6 \mathrm{t}-1}-0.059622 \Delta \mathrm{x}_{7 \mathrm{t}-1}+2.09 \mathrm{E}-05 \Delta \mathrm{y}_{\mathrm{t}-1}-0.277907 \mathrm{EC}$
$(-0.45)$
$(0.65)$
$(-0.36)$
$(0.27)$
$(-1.79)$

$\mathrm{R}^{2}=0.2 \quad \mathrm{~F}=1.04, \quad \mathrm{AIC}=4.31, \quad \mathrm{SC}=4.72$

[7] $\Delta \mathrm{x}_{7 \mathrm{t}}=1.557461+0.064348 \Delta \mathrm{x}_{1 \mathrm{t}-1-1}-0.445270 \Delta \mathrm{x}_{2 \mathrm{t}-1}-0.675446 \Delta \mathrm{x}_{3 \mathrm{t}-1}+0.033164 \Delta \mathrm{x}_{4 \mathrm{t}-1}$
$(4.24) *(0.58)$
$(-0.97)$
$(-4.22)^{*}$
$(0.57)$

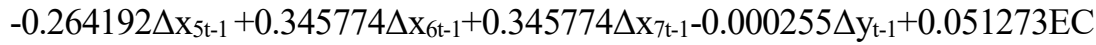
$(-0.90)$
$(0.49)$
$(2.11)^{*}$
$(-3.33)^{*}$
(0.33) 
$\mathrm{R}^{2}=0.59, \mathrm{~F}=5.32^{*}, \quad \mathrm{AIC}=4.29, \mathrm{SC}=4.7,{ }^{*}=$ significant,$\Delta \mathrm{x}_{7 \mathrm{t}}$ and $\Delta \mathrm{x}_{7 \mathrm{t}-1}$ are positively related significant and $\Delta \mathrm{x}_{7 \mathrm{t}}$ and $\Delta \mathrm{y}_{\mathrm{t}-1}$ are negatively related significantly.

[8] $\Delta \mathrm{y}_{\mathrm{t}}=2834.112-89.85084 \Delta \mathrm{x}_{1 \mathrm{t}-1}+842.2183 \Delta \mathrm{x}_{2 \mathrm{t}-1}-1391.315 \Delta \mathrm{x}_{3 \mathrm{t}-1}-174.3453 \Delta \mathrm{x}_{4 t-1}-1692.335 \Delta \mathrm{x}_{5 \mathrm{t}-1}$
$(2.86)^{*}$
$(-0.3)$
$(0.68)$
$(-3.22)^{*}$
$(-1.11)$
$(-2.14)^{*}$

$+155.3180 \Delta \mathrm{x}_{6 \mathrm{t}-1}+147.5783 \Delta \mathrm{x}_{7 \mathrm{t}-1}-0.348757 \Delta \mathrm{y}_{\mathrm{t}-1}+202.9272 \mathrm{EC}$

$(0.21)$

$(-1.69)$

$(0.49)$

$\mathrm{R}^{2}=0.42 \mathrm{~F}=2.71, \mathrm{AIC}=20.09, \mathrm{SC}=20.50,{ }^{*}=$ significant, $\Delta \mathrm{y}_{\mathrm{t}}, \Delta \mathrm{x}_{5 \mathrm{t}-1}$ and $\Delta \mathrm{x}_{3 \mathrm{t}-1}$ are negatively related significantly.

This VECM is good fit for equations [1] $\Delta \mathrm{x}_{1 \mathrm{t}}$, [2] $\Delta \mathrm{x}_{2 \mathrm{t}}$ and [7] $\Delta \mathrm{x}_{7 \mathrm{t}}$. The speed of the vector error correction process is more or less slow except for $\Delta \mathrm{x}_{2 \mathrm{t}}$ and $\Delta \mathrm{x}_{4 \mathrm{t}}$ which are significant. $\Delta \mathrm{x}_{2 \mathrm{t}}$ has been correcting the error by $23.16 \%$ per year and $\Delta \mathrm{x}_{4 \mathrm{t}}$ has been correcting the error by $102.55 \%$ per year respectively.

Yet this VECM is stable since it has 10 roots in which six roots are imaginary $(0.518961 \pm 0.209573 i$, $0.308760 \pm 0.428752 \mathrm{i},-0.165298 \pm 0.346439 \mathrm{i})$, one root is one and other three roots $(-0.543200,0.328063$, 0.138599 ) are less than one, all of which lie in the unit circle. It is shown in the Figure 4.

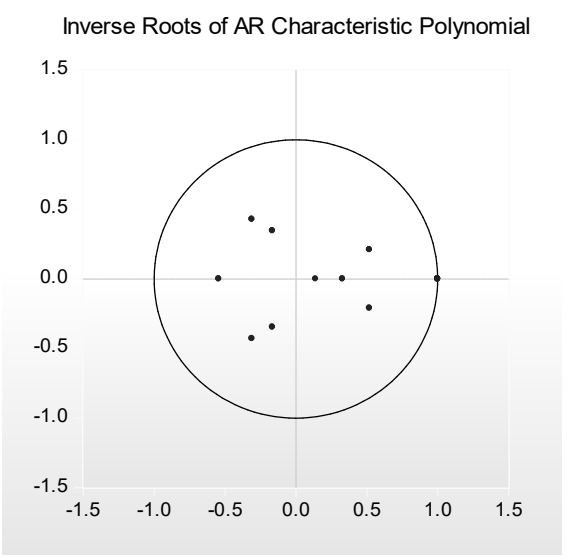

Figure 4. Unit circle

Source-Computed by author

The Impulse Response Functions of VECM have been diverging away from equilibrium which means that exogenous shocks do not turn the model into equilibrium. It is shown in Figure 5 (response of $\mathrm{x}_{1}, \mathrm{x}_{2}, \mathrm{x}_{3}, \mathrm{x}_{4}$, $\mathrm{x}_{5}, \mathrm{x}_{6}, \mathrm{x}_{7}, \mathrm{y}$ to Cholesky one SD innovations). These lines are moving away from zero. It means that the VECM is non-stationary.

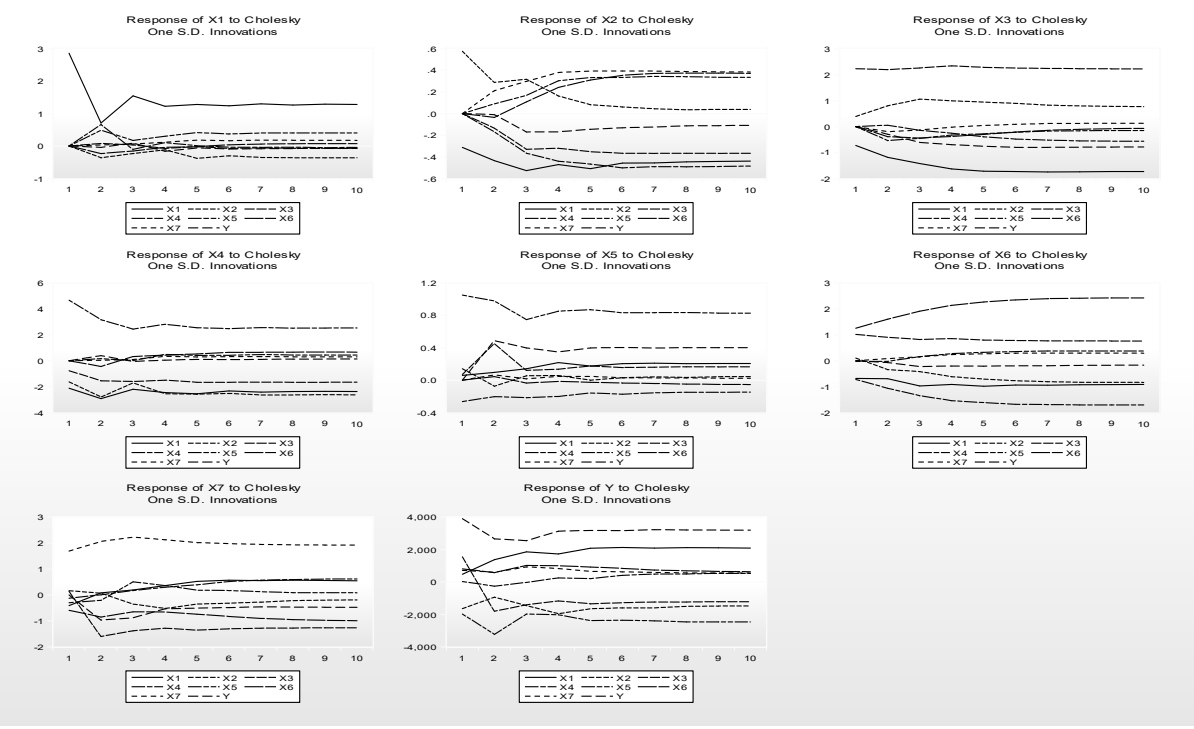

Figure 5. Impulse Response Functions.

Source- Plotted by author. 
Residual tests of this VECM assure that the residuals have the problem of autocorrelations which is shown in Figure 6.

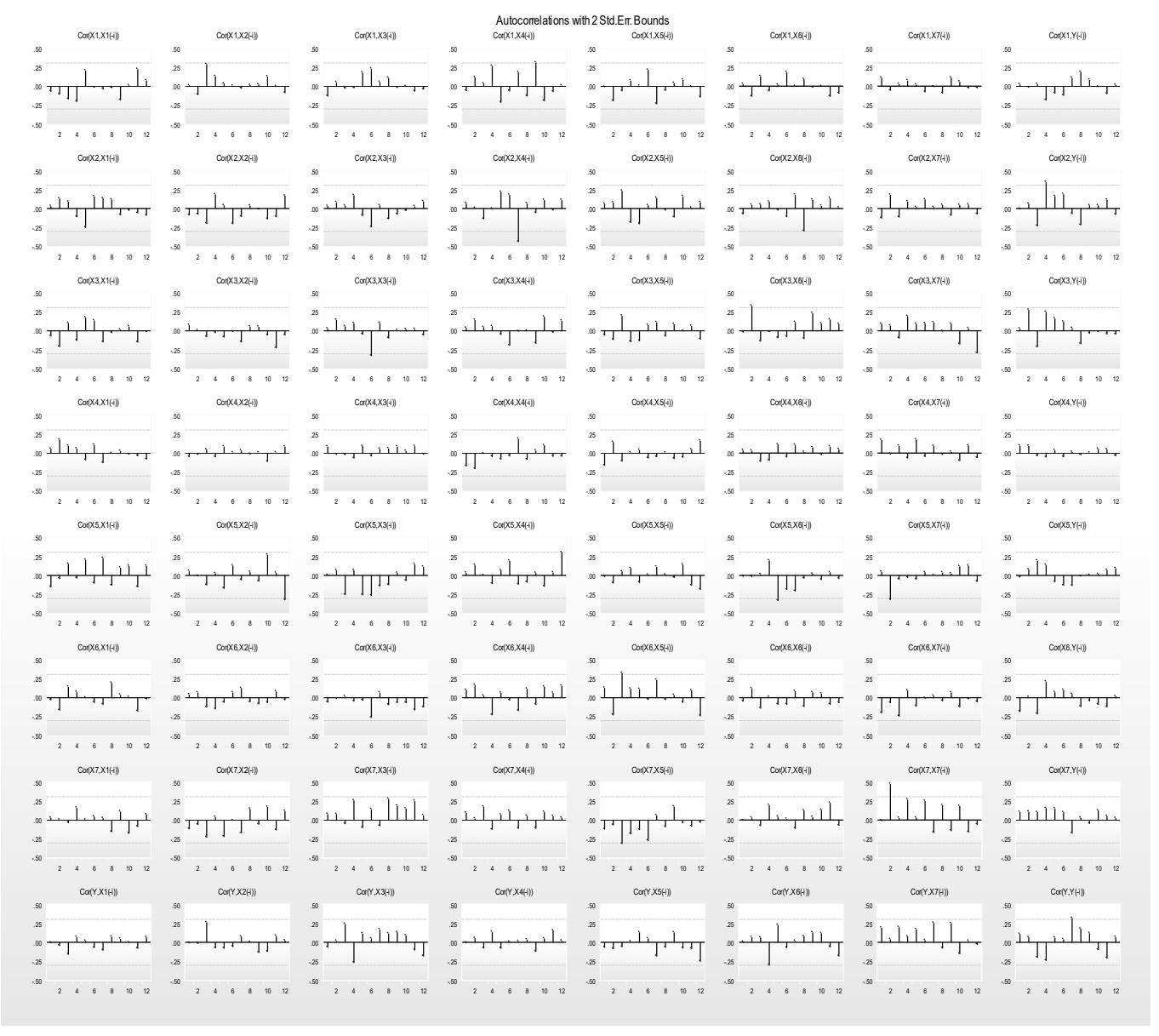

Source-Plotted by author

Figure 6. Autocorrelations problem

The Serial correlation LM test of the residuals of the Vector Error Correction Model suggested that the variables are serially correlated which is seen in the Table 4.

Table 4. Serial correlation LM test

\begin{tabular}{|c|c|c|}
\hline Lags & LM-Stat & Prob \\
\hline 1 & 69.08543 & 0.3097 \\
\hline 2 & 76.00517 & 0.1447 \\
\hline 3 & 60.44998 & 0.6028 \\
\hline 4 & 67.75267 & 0.3504 \\
\hline 5 & 51.45797 & 0.8709 \\
\hline 6 & 82.35328 & 0.0610 \\
\hline 7 & 63.05198 & 0.5100 \\
\hline 8 & 61.63928 & 0.5605 \\
\hline 9 & 56.77821 & 0.7272 \\
\hline 10 & 42.09907 & 0.9844 \\
\hline 11 & 65.69198 & 0.4180 \\
\hline 12 & 75.12452 & 0.1612 \\
\hline
\end{tabular}

Source-Calculated by author

The VEC residual normality test as done by Hansen-Doornik (1994) methodology has shown that the joint components of Kurtosis and Jarque-Bera are significant but most of the other components of Skewness, Kurtosis and Jarque-Bera are not significant according to the values of Chi-square distribution, therefore, the residuals are not multivariate normal. In Table 5, their values are given. 
Table 5. Hansen-Doornik normality test

\begin{tabular}{|c|c|c|c|c|}
\hline Component & Skewness & Chi-square & $\mathrm{df}$ & Probability \\
\hline 1 & -0.084242 & 0.064756 & 1 & 0.7991 \\
\hline 2 & -0.194496 & 0.341888 & 1 & 0.5587 \\
\hline 3 & 0.158327 & 0.227451 & 1 & 0.6334 \\
\hline 4 & -0.642132 & 3.360874 & 1 & 0.0668 \\
\hline 5 & -0.460680 & 1.822804 & 1 & 0.1770 \\
\hline 6 & 0.710372 & 4.022242 & 1 & 0.0449 \\
\hline 7 & 0.395926 & 1.367554 & 1 & 0.2422 \\
\hline 8 & 0.672477 & 3.650127 & 1 & 0.0561 \\
\hline Joint & & 14.85770 & 8 & 0.0620 \\
\hline Component & Kurtosis & Chi-square & $\mathrm{df}$ & Prob. \\
\hline 1 & 2.806869 & 0.180811 & 1 & 0.6707 \\
\hline 2 & 3.673029 & 3.119953 & 1 & 0.0773 \\
\hline 3 & 2.743956 & 0.054829 & 1 & 0.8149 \\
\hline 4 & 8.172222 & 31.27463 & 1 & 0.0000 \\
\hline 5 & 3.160990 & 0.104753 & 1 & 0.7462 \\
\hline 6 & 5.533883 & 7.996608 & 1 & 0.0047 \\
\hline 7 & 2.384901 & 1.219767 & 1 & 0.2694 \\
\hline 8 & 3.384075 & 0.017875 & 1 & 0.8936 \\
\hline Joint & & 43.96922 & 8 & 0.0000 \\
\hline Component & Jarque-Bera & $\mathrm{df}$ & Probability. & \\
\hline 1 & 0.245568 & 2 & 0.8845 & \\
\hline 2 & 3.461841 & 2 & 0.1771 & \\
\hline 3 & 0.282280 & 2 & 0.8684 & \\
\hline 4 & 34.63550 & 2 & 0.0000 & \\
\hline 5 & 1.927557 & 2 & 0.3814 & \\
\hline 6 & 12.01885 & 2 & 0.0025 & \\
\hline 7 & 2.587321 & 2 & 0.2743 & \\
\hline 8 & 3.668003 & 2 & 0.1598 & \\
\hline Joint & 58.82692 & 16 & 0.0000 & \\
\hline
\end{tabular}

Source-Calculated by author.

\section{Analytical framework of financial crises and FDI}

Capital inflows played a great role in financial crises in which foreign direct investment is of primary importance because current account imbalance during financial crises is somehow corrected through capital inflows or huge foreign direct investment for getting boosting output and growth. A 1\% increase in FDI/GDP ratio is followed by a $0.80 \%$ increase in future domestic investment/GDP in Africa. The anticipated decline crisis would therefore adversely affect the country's performance. (Mwega, 2009)

In 1914, total foreign investment of USA (FI = FDI + FPI) was 19.5\% of GNP while FDI was 4.7\%. By 1918, the total (FI) was down to $3.9 \%$ while FDI was $1.3 \%$. The 1920 s did not change these percentages very much but the 1930 s raised them so that by 1939 they stood at $6.8-9.6 \%$ and $3.2 \%$, respectively. By the end of World War II, total FI was $3.7 \%$ and FDI was $1.3 \%$. Wilkins's rich account of foreign investment in the U.S. is also a major part of the story of the retreat from the pre-World War I high-tide of globalization. (Wilkins,2005)

In the post war period, British and France lost foreign investment amounting in all to somewhere between 4 and 5 billion dollars i.e. approximately $25 \%$ of British and $50 \%$ of French prewar foreign investment although in 1914,34 countries (10 developed and 24 less developed countries) produced $97 \%$ of world GDP and received $92 \%$ of British capital which spread into wider area and moved to Brazil, Mexico, Chile, Egypt, South Africa, India, Russia and Far East. During and after the War Germany lost practically all her foreign investment amounting to sum 5-8 billion dollars. After the first world war, British foreign investment in third world was stagnant, the Netherlands, Belgium and Japan all expanded their investment into their colonies rather continually up to world war II, while not having appreciable FDI in the rest of the third world. (Twomey,2002)

In 1915, the British FDI was 43 million pound which increased to 110 million pound in 1916 and then started to decline and stood 60 million pound in 1917 and 23 million pound in 1918 respectively. On the other hand, during 1924-30, 10-11 billion dollar capital flowed in the world in which $60 \%$ came from USA, $15 \%$ from UK and France and balance from Switzerland, Netherland, Czechoslovakia and Sweden respectively. In the 1930s the crisis was global because the great depression was global. Assuming 1929 as 100, the world trade index fell to 39, export value and import price declined to 74 and 52 respectively and world industry production, 
Europe and North American industry production fell down to 64,42, and 54 respectively in 1932 as 1929 as the base. Even the value of export sharply fell to 45 for Germany, 39 for France, 36 for UK and 40 for Europe.

FDI had a strong negative effects in the Baring Crises of 1890, the American Panic of 1907, the Financial Crises of July-August 1914, the banking crises of the Great Depression of the 1930s, the Financial Instability of the early 1970s, the International Debt Crisis of 1982, the Japanese Banking Crisis of 1997-8, and the US Financial Debacle of 2007-8, and Euro crisis of 2009-10, respectively.

In Figure 7, the judgement index of extent of capital mobility is measured in the left vertical axis and is marked by red line. The share of countries in Banking crisis (3 year sum) is measured in the right hand vertical axis and is marked by blue line. The capital mobility is classified into low, medium and high during 1880-2007.The low and moderate capital mobility was seen during 1800-1879. Only low capital mobility was observed during 1915-1919 and 1930-1969, only moderate capital mobility was seen during 1920-1929 and 1970-1979, and only high capital mobility was seen during 1880-1914 and 1980-2007 respectively. During 1800-1979, 17 low, medium and high income countries fell into banking crises, during 1880-1914, total 19 countries fell into banking crisis, during 1915-1919, only one country showed the crisis, during 1920-1929, total 13 countries, during 1930-1969, total 10 countries, during 1970-1979, total 7 countries and during 1980-2007, total 51 countries fell into banking crisis respectively. Therefore, it is fact that as capital mobility moves from low to high level, the share of countries with banking crises tends from low to high. This means capital flows may lead to financial crises.

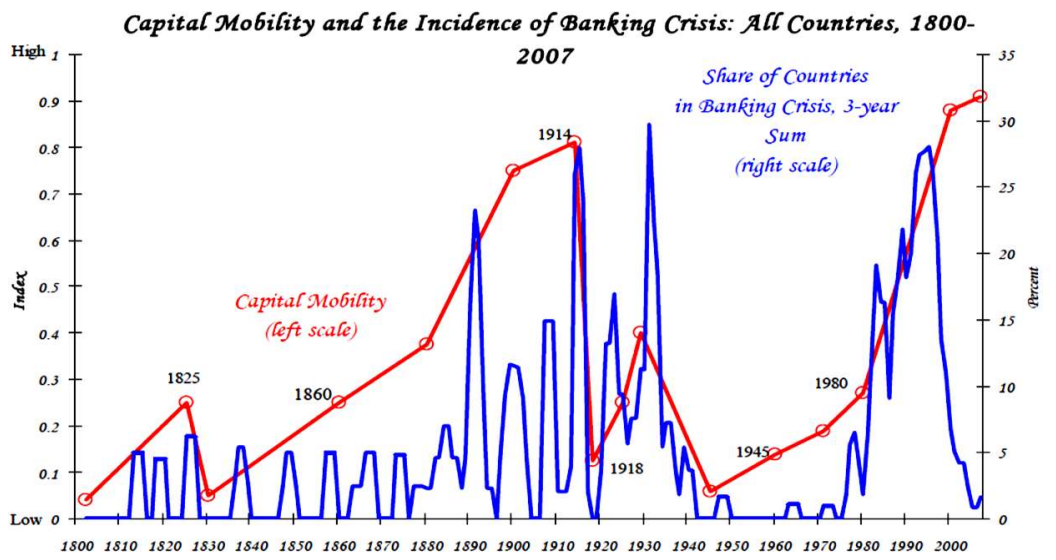

Figure 7. Capital mobility and banking crisis during 1800-2007

Source: Reinhart and Rogoff (2008).

More or less similar pattern of foreign investment had been observed in different international monetary system during 1860-2000 where the gold standard had enjoyed the maximum benefit from the foreign investment as was evident in 1900s but there was a sharp fall of the foreign investment in all the financial crises as observed in the monetary systems (Figure 8). In the gold standard during 1860-1914, Britain's supremacy of FDI flows in the world was noticed and the Gold Standard broke down in 1931. The War and the depression in the interwar period there was the great fall of world FDI flows although US FDI outflows began to increase. After the Bretton Woods, the FDI flows started to increase speedily where US dominance could not be ignored but Japan's hegemony in 80s and 90s is the important phenomenon when floating exchange rate in the international monetary system was activised after the break down of Bretton Woods and US dominance in foreign capital started to decline due to emergence of capital flows from Euro Area under European Monetary System (Also see Bhowmik, 2016). 


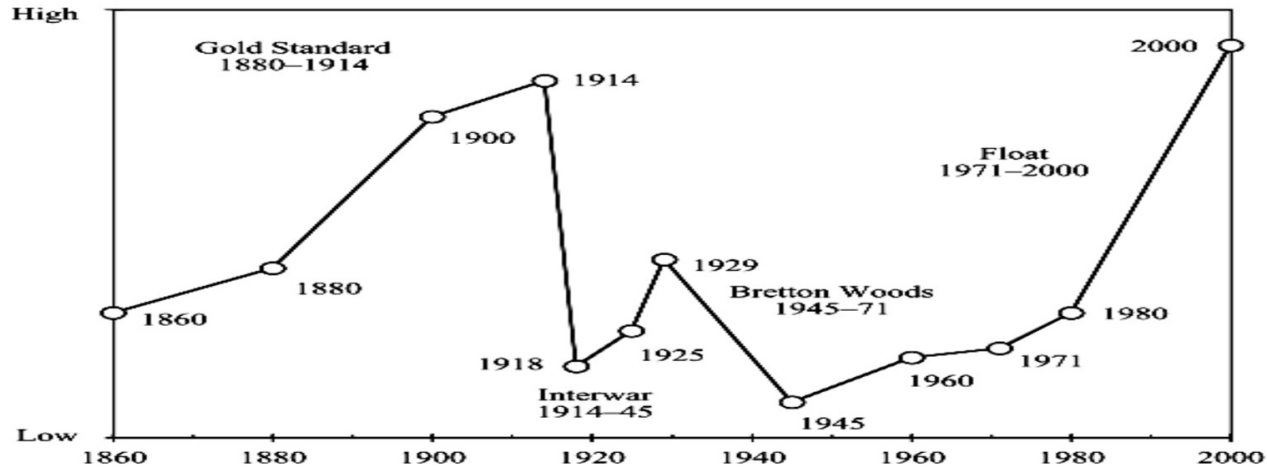

Figure 8. Trend of Foreign investment in different monetary system during 1860-2000

Source: Obstfeld and Taylor (2002).

FDI inflows declined only in the Developing and SAARC countries and outflows of FDI declined only in NAFTA and no other countries or blocs had no major adverse impact as a result of Financial crisis in 1970.The oil shock of 1979 along with Mexican crisis had a great impact of declining donor countries FDI flows but the developed countries shortfall of inflows were seen only in 1980 but no adverse impact of FDI inflows was observed (Table 6).

Table 6. FDI flows during the crises of 1970 and 1979

\begin{tabular}{|c|c|c|c|c|c|c|c|c|}
\hline & \multicolumn{8}{|c|}{ FDI inflows (million Dollar) } \\
\hline & 1970 & 1971 & 1972 & 1973 & 1979 & 1980 & 1981 & 1982 \\
\hline Developing $\mathrm{C}$ & 3854 & 3631 & 3423 & 5175 & 8505 & 7469 & 24003 & 26353 \\
\hline SAARC & 68 & 49 & 35 & 36 & 148 & 203 & 255 & 203 \\
\hline ASEAN & 459 & 559 & 596 & 1245 & 1698 & 2636 & 3596 & 3624 \\
\hline USA & 1260 & 870 & 1350 & 2120 & 8700 & 16918 & 25195 & 13810 \\
\hline UK & 1488 & 1771 & 1207 & 2722 & 6469 & 10122 & 5879 & 5413 \\
\hline NAFTA & 3395 & 3449 & 3641 & 5761 & 14539 & 24824 & 28932 & 15834 \\
\hline Japan & 94 & 210 & 169 & -42 & 239 & 278 & 189 & 439 \\
\hline EuroArea & 3457 & 3881 & 5020 & 6487 & 10443 & 10791 & 9915 & 8291 \\
\hline & \multicolumn{8}{|c|}{ FDI Outflows (million Dollar) } \\
\hline Dev.C & 14100 & 14395 & 15656 & 25808 & 62453 & 48397 & 49931 & 24803 \\
\hline NAFTA & 8521 & 8075 & 7027 & 12518 & 30320 & 23331 & 18806 & 3575 \\
\hline Euro Area & 3144 & 3591 & 4543 & 5687 & 15438 & 13180 & 14705 & 10347 \\
\hline USA & 7590 & 7618 & 7747 & 11353 & 26493 & 19230 & 13227 & 1078 \\
\hline UK & 1678 & 1988 & 2017 & 4981 & 12539 & 7881 & 9386 & 3707 \\
\hline Japan & 355 & 360 & 723 & 1904 & 5965 & 6440 & 14402 & 20101 \\
\hline
\end{tabular}

Source: www.unctad.org.

FDI inflows in South America including Brazil declined steadily and could not reach its peak level of 1970.There were marginal adverse effects in the developing countries and Argentina in 1983 only. No donor countries' FDI outflows fell abruptly except in LAIA, Japan and Brazil in 1983 because of International debt crisis in 1982 and oil shock (Table 7).

Table 7. International debt crisis and oil shock in 1982

\begin{tabular}{|l|c|c|c|c|c|}
\hline & \multicolumn{5}{|l|}{} \\
\hline & 1982 & 1983 & 1984 & 1985 & 1986 \\
\hline Argentina & 227 & 185 & 268 & 919 & 574 \\
\hline Brazil & 3115 & 1326 & 1501 & 1418 & 317 \\
\hline Mexico & 1900 & 2191 & 1540 & 1983 & 2400 \\
\hline Caribbean & 132 & 89 & 895 & 294 & 259 \\
\hline Developing C & 2074 & 1322 & 1884 & 2442 & 1770 \\
\hline S. American C & 4498 & 2659 & 1561 & 3699 & 1765 \\
\hline & \multicolumn{5}{|c|}{ FDI Outflows (million dollars) } \\
\hline USA & 1078 & 9525 & 13045 & 13388 & 19641 \\
\hline UK & 3707 & 5302 & 7733 & 11068 & 17294 \\
\hline Japan & 4540 & 3612 & 5965 & 6440 & 14402 \\
\hline Brazil & 376 & 188 & 42 & 81 & 144 \\
\hline Argentina & -30 & 2 & 44 & 11 & 48 \\
\hline Euro Area & 10347 & 10759 & 12252 & 13255 & 24964 \\
\hline
\end{tabular}


Table 7 (cont.). International debt crisis and oil shock in 1982

\begin{tabular}{|l|c|c|c|c|c|}
\hline FTAA & 4566 & 12555 & 16867 & 17881 & 24377 \\
\hline LAIA & 1164 & 425 & 112 & 580 & 1088 \\
\hline
\end{tabular}

Source-www.unctad.org.

Asian financial crisis and Japanese banking crisis broke out in mid 1990s where depreciation of currencies, decline of growth rate and employment, shuttered financial integration and disrupted capital flows. But the impact of this crisis in EU, USA, Africa was nil in case of FDI inflows but there is little impact of FDI inflows in China, India, Asia and South East Asia where inflows declined from 1998 in China and India, and declined only in 1998 in South Asia, East Asia and South East Asia. On the contrary, Japanese FDI outflows fell down sharply since 1997 and Chinese FDI outflows fell down only in 1999 but India's outflows declined from 1997. Other regional outflows were undisturbed. (Table 8).

Table 8. Capital Flows in Asian financial crises

\begin{tabular}{|l|c|c|c|c|c|c|c|c|c|}
\hline & \multicolumn{10}{|c|}{ FDI Inflows (million Dollar) } \\
\hline & EU & USA & China & India & Japan & Africa & SA, EA, SEA & W. Asia & LAC \\
\hline 1995 & 113480 & 58772 & 35849 & 2144 & 39 & 4694 & 73639 & -2 & 12765 \\
\hline 1996 & 109642 & 84455 & 40180 & 2591 & 200 & 5622 & 89406 & 2892 & 20585 \\
\hline 1997 & 127626 & 103398 & 44237 & 3613 & 3200 & 7153 & 98507 & 5488 & 25889 \\
\hline 1998 & 261141 & 174434 & 43751 & 2614 & 3268 & 7713 & 86004 & 6580 & 29898 \\
\hline 1999 & 467154 & 294976 & 40319 & 2154 & 12741 & 8971 & 96224 & 936 & 34422 \\
\hline 2000 & 617321 & 281115 & 40772 & 2315 & 8149 & 8198 & 137348 & 3427 & 31090 \\
\hline \multicolumn{8}{|c|}{ FDI Outflows (million Dollar) } \\
\hline 1995 & 159036 & 92074 & 2000 & 119 & 22508 & 509 & 41824 & -991 & 7306 \\
\hline 1996 & 183180 & 84424 & 2114 & 244 & 23442 & 28 & 49683 & 2273 & 5549 \\
\hline 1997 & 220416 & 95769 & 2563 & 113 & 26059 & 1708 & 49482 & -281 & 14391 \\
\hline 1998 & 454266 & 131004 & 2634 & 48 & 24152 & 897 & 29985 & -1698 & 8048 \\
\hline 1999 & 720052 & 142551 & 1775 & 79 & 22743 & 632 & 34447 & 656 & 21753 \\
\hline 2000 & 772949 & 139259 & 2324 & 336 & 32886 & 744 & 83641 & 1284 & 13442 \\
\hline
\end{tabular}

Source-World Investment Report-2001.

The first indications of a global financial crisis emerged in the middle of 2007 with rising defaults on subprime mortgages in the U.S. Not only private financial institutions (such as Lehman Brothers and Morgan Stanley), but even nations (such as Iceland) found themselves on the verge of bankruptcy. As financial institutions have been increasingly forced to raise capital and tackle the liquidity problem, decreasing international bank lending, falling stock exchanges, declining portfolio investment, and initial public offerings (IPOs) put the international financial market on hold.

Subsequently, Euro debt crisis began and spill over globally which had tremendous adverse impact on current account balance, output and financial market too in EU and abroad. International liquidity on Euro fell down and FDI flows declined abruptly (Bhowmik,2014).

Global FDI hit a record peak in 2007 ( 2 trillion US\$ or 16\% of world gross fixed capital formation) but dropped sharply in 2008 for both inward and outward FDI flows (34\% for outflows and 52\% for inflows). While incoming FDI flows recovered slightly in 2009 and EU FDI outflows continued to decline by $24 \%$ and total world flows in 2010 reduced to 1 trillion US\$. In Table 9, FDI inflows of USA, EU, Africa, West Asia, India, Japan and developing countries declined from 2008 or 2009 but FDI inflows in China, South East Asia, East Asia and Latin America and Caribbean dwindled only in 2009 and then revived. On the other hand, FDI outflows of EU, USA and Japan who are dominant donor of FDI fell down sharply from 2008 but there was little impact of FDI outflows of developing countries, South East Asia, East Asia and China although India's FDI outflows declined from the beginning of the financial crisis. It was also well known that the growth rates of developed countries and the EU declined during the crisis. The revival of EU has started in last year after collapse of Euro crisis. Conversely the extent of decrease in GDP growth rates was smaller in some Asian countries than Europe and America. In Figure 9, the global FDI flows and growth moved towards the similar direction downward since the crisis but there was no recovery of FDI although the growth started to recover.

Table 9. Capital flows in recent financial crises

\begin{tabular}{|l|l|l|l|l|l|l|l|l|l|l|l|}
\hline & \multicolumn{1}{|c|}{ FDI Inflows (million Dollar) } \\
\hline & EU & USA & China & India & Japan & Dev.C. & Africa & SEA & W. Asia & LAC & EA \\
\hline 2007 & 906531 & 215952 & 83521 & 25350 & 22550 & 589430 & 51274 & 85640 & 79609 & 171929 & 165104 \\
\hline
\end{tabular}


Table 9 (cont.). Capital flows in recent financial crises

\begin{tabular}{|l|l|l|l|l|l|l|l|l|l|l|l|}
\hline 2008 & 571797 & 306366 & 108312 & 47139 & 24426 & 668439 & 58894 & 50543 & 93546 & 210679 & 195454 \\
\hline 2009 & 404791 & 143604 & 95000 & 35657 & 11939 & 530289 & 52964 & 47810 & 71919 & 150150 & 162523 \\
\hline 2010 & 429230 & 197905 & 114734 & 21125 & 1251 & 637063 & 43582 & 97898 & 59459 & 189855 & 214604 \\
\hline 2011 & 472852 & 226937 & 123985 & 36190 & 1755 & 735212 & 47598 & 109044 & 49058 & 249432 & 233818 \\
\hline 2012 & 275580 & 167620 & 121080 & 25542 & 1731 & 702826 & 11502 & 111336 & 47119 & 243861 & 214804 \\
\hline \multicolumn{8}{|c|}{ FDI Outflows (million Dollar) } \\
\hline 2007 & 1257890 & 393518 & 26510 & 17234 & 73548 & 330033 & 11081 & 59640 & 34063 & 80257 & 127132 \\
\hline 2008 & 982036 & 308296 & 55910 & 21147 & 128019 & 344034 & 10080 & 32255 & 37680 & 97773 & 143509 \\
\hline 2009 & 381955 & 266955 & 56530 & 16031 & 74699 & 273401 & 6281 & 39345 & 17890 & 55512 & 137783 \\
\hline 2010 & 497801 & 304399 & 68811 & 15933 & 56263 & 413220 & 9311 & 47414 & 13398 & 119236 & 206777 \\
\hline 2011 & 536499 & 396656 & 74654 & 12456 & 107601 & 422067 & 5376 & 58957 & 26184 & 105154 & 212519 \\
\hline 2012 & 329131 & 328869 & 84220 & 8583 & 122551 & 426082 & 14296 & 60592 & 23941 & 103045 & 214409 \\
\hline
\end{tabular}

Source: World Investment Report-2013.

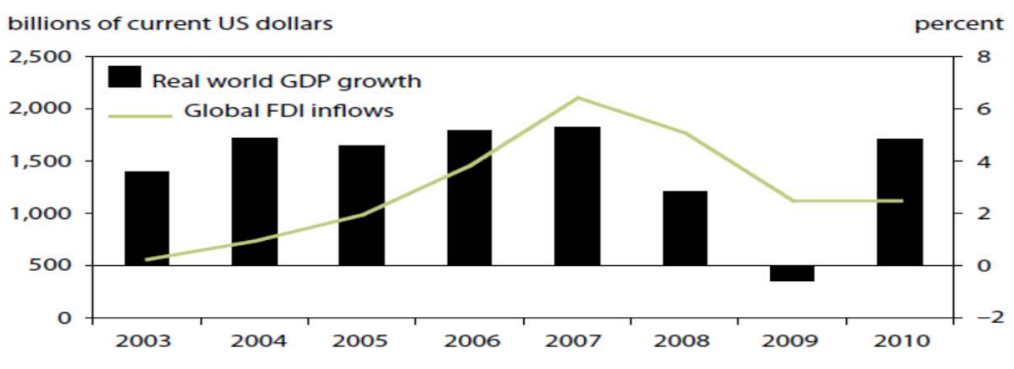

Sources: United Nations Conference on Trade and Development; International Monetary Fund.

Figure 9. Global FDI and Growth since crisis

Financial crises were often proceded by asset and credit booms that eventually turn into busts. Some historical asset price bubbles and crashes are well known: Dutch Tulip Mania from 1634-1637, the French Mississippi Bubble in 1719-20 and the South Sea Bubble in UK in 1720. European financial crisis of 1763, which involved highly levered and interlocked financial ties between Amsterdam, Hamburg, and Prussia and resulted insignificant asset resale that affected by market participants. The major banking crises occurred in the U.S. in 1837 and in 1857. After the creation of a national U.S. banking system, banking panics occurred again (in varied forms) in 1873, 1884, 1893, 1907, and 1914. The Great Depression ultimately caused a full-blown international banking crisis. The South American debt crises led to the Brady Plan in 1989. A painful bust occurred in Scandinavia in the early 1990s by banking crises in Finland, Norway, and Sweden. The burst of the bubble led to large drops in output in all three countries. Japan also suffered a major financial crisis in the early 1990s. In 1997 and 1998, the focus fell on East Asian countries and Russia. After large equity and real estate booms in East Asia, a run on Thailand's currency (the baht) led to a reversal of international capital flows to the entire region, triggering a financial crisis that quickly spread to other East Asian countries, such as Indonesia and Korea. In 2001, Argentina was unable to sustain the level of public sector debt it had accumulated over the 1990s. In January 2002, Argentina suspended the peso's peg to the dollar. Within a few days, the peso lost much of its value. The crisis led to a severe decrease in GDP and a spike in inflation. Ultimately, Argentina defaulted on its debts. In 2007-08, the US financial crisis began and spread over the world. The great financial crisis of 2008 in EU led to debt crises in Greece, Ireland, Italy, Portugal, and Spain. These crises known as Euro crisis also highlight the intimate connection between banking crises and sovereign debt crises (Bhowmik, 2014).

Laeven \& Valencia (2013) reported that there are 147 banking crises, 217 currency crises, and 67sovereign debt crises over the period 1970 to 2011. Currency crises frequently tend to overlap with banking crises - so called twin crises (Kaminsky \& Reinhart, 1999). In addition, sudden stop crises, not surprisingly, can overlap with currency and balance-of-payments crises, and sometimes sovereign crises. Of the 431, banking (147), currency (217) and sovereign (67) crises Laeven \& Valencia (2013) reported that they consider 68 as twin crises, and 8 can be classified as triple crises. (Figure 10). A systemic banking crisis, for example, often involves a currency crisis and a sovereign crisis sometimes overlaps with other crises, 20 out of 67 sovereign crises are also a banking and 42 also a currency crisis. Laeven \& Valencia (2013), estimate that fiscal costs, 
net of recoveries, associated with crisis are on average about 6.8 percent of GDP. They can, however, be as high as 57 percent of GDP and in several cases are over 40 percent of GDP (for example Chile and Argentina in the early 1980s, Indonesia in the later 1990s, and Iceland and Ireland in 2008). Debt crises are more costly than banking and currency crises and are typically associated with output declines of 3-5 per cent after one year and 6-12 per cent after 8 years. Using a larger sample, Laeven \& Valencia (2013) reported the median increase in public debt to be about 12 per cent for their sample of 147 systemic banking crises. Sudden stops are especially costly. Using a panel data set over 1975-1997 and covering 24 emerging markets, Glick \&Hutchison (2011) finds that while a currency crisis typically reduces output by $2-3 \%$, a sudden stop reduces output by an additional 6-8 per cent in the year of the crisis. The cumulative output loss of a sudden stop is even larger, about $13-15$ percent over a 3 -year period.
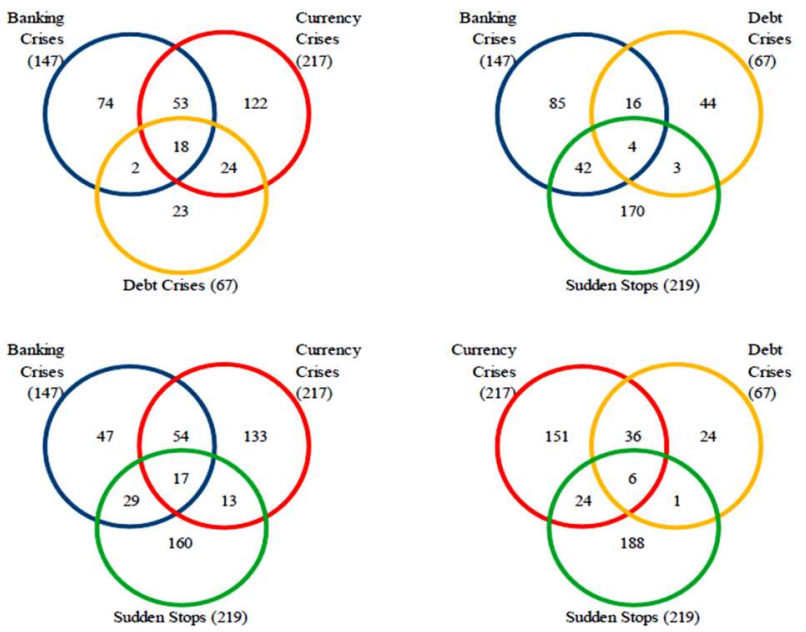

Figure 10. Coincidence of Financial Crises

Source-Laeven \& Valencia (2013).

\section{Limitations of the study}

There are many determinants of FDI in the economy as suggested by existing literature available as on now, in which author has not included the following factors namely,(i) Market Size(ii) Portfolio Diversification(iii) Resource Location(iv) Differential Rate of Return(v) Foreign Exchange Reserves(vi) Internationalization (vii) Government Regulations(viii) Political Stability(ix) Tax Policies(x) Industrial Organization (xi) technology ,(xii) human capital respectively. The choice variables depend on the needs of the economy. Some of the determinants are lag variables. Therefore, a single model cannot forecast all the relationships nor co-integration analysis is sufficient to explain qualitative and quantitative importance of the variables. Even, the models that are framed clearly are country specific and time dependent. Besides, the host countries' behavior of FDI inflows in the developing countries are rather different than the developed countries.

\section{Scope of Future research}

There is huge scope of further research in the area. One can find root causes of banking crisis, currency crisis and sovereign debt crisis and can relate with growth either in a specific country or in regions during long period of time. How monetary and fiscal policies affect on those crises can be analyzed. One can highlight the Concept of Political economy of those crises. Above all, the periodical differences are very much importance in these fields. The paper demands historic and academic interests as well. More analysis can be done in the cases where FDI decline in every financial crisis regionally or sub-regionally. Even, why China and other East Asian countries did not react negatively too much in recent crises is to be an added future studies.

In this model, FDI inflows in India had no causal relation with the openness during the study period whose inherent causes are to be searched in the offing. How far historical domination of FDI in India has changed is the important area of research in context of the paper.

\section{Some recommended policies}

Some general economic policies are urgent like [i] to reduce current account deficit, [ii] to reduce external debt, [iii] to cut down fiscal deficit, [iv] to fix target rate of inflation, [v] to follow monetary policy to reduce interest rate when needed, [vi] to increase trade openness respectively to get fruitful outcome of FDI inflows, 
[vii] to increase weight on infrastructure improvements, training productive workers, and encouraging domestic firms to invest in technology in order to achieve sustained benefits from FDI, [viii] to relate productivity with FDI inflows, and employment with FDI inflows, [ix] to stimulate knowledge transfer in labour training and skill development, [x] to introduce alternative management practices, [xi] to form an honest and uncorrupted government, [xii] to study feasibility of FDI in various sectors and subsectors of the economy,[xiii] to compute potentiality of employment generation on the impact of FDI inflows in India.

\section{Concluding remarks}

The paper concludes that FDI inflows in India have been catapulting at the rate of $21.56 \%$ per year during 1971-2015 and exponentially at the rate of $0.6044 \%$ per year significantly. It has four upward structural breaks in 1985,1994, 2000 and 2006 respectively during the specified period. FDI inflows in India has causal relation uni-directionally with fiscal deficit, and bi-directionally with inflation, exchange rate, interest rate and growth rate during 1971-2015.Johansen co-integration test confirmed that Trace Statistic contains four co-integrating equations and Max Eigen Statistic has three co-integrating equations. VECM is stable, non-stationary and not good fit for four estimated equations and error corrections for the equations of change of interest rate and inflation rate showed significant with speeds of $23 \%$ and $103 \%$ per year.

The paper also concludes that FDI does not cause Granger financial crises but financial crises do cause Granger FDI. In every financial crisis since 1890, FDI changes downward but in Euro crises and US subprime crises, FDI did not decline in most of the East Asian countries. The declining growth and FDI in all financial crises were the general phenomenon. Also in India, financial crises had negative impact on FDI and growth.

In concluding remarks we like to mention that a country which has a stable macroeconomic condition with high and sustained growth rates will receive higher FDI inflows than a more volatile economy. Therefore, it is expected that GDP growth rate, industrial production, and interest rates would influence FDI flows positively and the inflation rate would influence positively or negatively. Market size plays an important role in attracting foreign direct investment from abroad. Market size is measured by GDP. Market size tend to influence the inflows, as an increased customer base signifies more opportunities of being successful and also the fact that with the rampant development the purchasing power of the people has also been greatly influenced moving to many levels higher in comparison to what it was before the economic growth.

\section{References}

1. Adeleke, Adegoke Ibrahim. (2014, March). FDI-growth nexus in Africa: Does governance matter? Journal of Economic Development, 39(1), 111-126

2. Adeniyi, Oluwatosin Ademola., Omisakin, Dr. Olusegun A., Egwaikhide, Festus., \& Oyinlola, Abimbola. (2012, March). Foreign Direct Investment, Economic Growth and Financial Sector Development in Small Open Developing Economies, Economic Analysis \& Policy, 42(1), Available at SSRN: https://ssrn.com/abstract $=2156883$

3. Anyanwu, J.C. (2012). Why Does Foreign Direct Investment Go Where It Goes? New Evidence from African Countries, Annals of Economics and Finance, 13(2), 433-70.

4. Banerjee, Anindya., Juan, Dolado., Galbraith, JohnW., \&Hendry, David F. (1993). Co-Integration, ErrorCorrection, and the Econometric Analysis of Non-Stationary Data, Oxford University Press.

5. Basu, P., Chakraborty, C., \& Reagle, D. (2003). Liberalization, FDI, and growth in developing countries: a panel cointegration approach. Economic Inquiry, 41(3), 510-516

6. Bhowmik, Debesh. (ed). (2016). International Monetary System: Past, Present and Future. New Delhi: Regal Publications.

7. Bhowmik, Debesh., \& Dey, T. (2014). Financial crises, US shut down and FDI, Paper presented in Department of Commerce, Kalyani University on 27-28 March at UGC seminar.

8. Bhowmik, Debesh. (2014). An analysis of financial integration: Now and then. Paper selected for presentation at World conference on Finance and Banking in Singapore, on 11-12 December.

9. Bhowmik, Debesh. (2014). FDI, financial crises and BW-II, The Indian Economic Journal, Special Number December, 1-18.

10. Bhowmik, Debesh. (2014). The Euro crisis and international Liquidity Problems.New Delhi: Synergy Books India.

11. Bhowmik, Debesh. (2003). Essays on International Money. New Delhi: Deep and Deep Publications Pvt.Ltd. 
12. Bhowmik, Debesh. (2011). US financial crisis, recovery packages and dollar hegemony, In Raj Kumar Sen (Ed.), Modern Indian Economy: Essays in honour of Prof.Alok Ghosh, New Delhi: Deep and Deep Publications Pvt.Ltd,26-37

13. Bhowmik, Debesh. (1999, December). Foreign Investment in India: Theories, evidences, policies, Artha Beekshan, 8(2),20-32.

14. Cairncross, A. K. (1953). Home and Foreign Investment 1870-1913, Cambridge University Press.

15. Chakrabarti, A. (2001). The determinants of foreign direct investment: sensitivity analyses of crosscountry regressions. Kyklos, 54, 89-113.

16. Chakraborty, C., \& Basu, P. (2003). Foreign Direct Investment and growth in India: A cointegration approach. Applied Economics, 34(9), 1061-1073

17. Chakraborty, Chandana \& Basu, Parantap. (2010, October). Foreign Direct Investment and growth in India: A Cointegration Approach.Applied Economics, 34(9), 1061-1073

18. Dash, R.K.\& Parida, P.C. (2011). Services trade and economic growth in India: an analysis in the postreform period. International Journal Economics Business Research,4(3),326-345

19. Dinda, Soumyananda. (2009). Factors attracting FDI to Nigeria: an Empirical Investigation. Madras School of Economics, Chennai, India.

20. Granger, C. W. J. (1969). Investigating Causal Relations by Econometric Models and Cross-spectral Methods, Econometrica, 37(3), 424-438.

21. Ewing, B.T., \&Yang, B. (2009). The differential growth effect of FDI across US regions. International Economic Journal,23(4),511-525

22. Glick, Reuven., \& Hutchinson, Michael. (2011, September). Currency crises,Federal Reserve Bank of San Fransisco, Working Paper No-2011/22.

23. Hansen, H., \& Rand, J. (2006). On the causal links between FDI and Growth in developing countries. The World Economy,29,21-43.

24. Hansen, H., \& Doornik, J. A. (1994). An omnibus test for univariate and multivariate normality Discussion paper, Nuffield College, Oxford University.

25. Herzer, D., Klasen, S., \& Nowak-Lehmann, D. F. (2008). In search of FDI-led growth in developing countries: The Way forward. Economic Modelling, 25(5),793-810

26. Johansen, S. (1988). Statistical Analysis of Co-integrating Vectors. Journal of Economic Dynamics and Control, 12, 231-254.

27. Johansen, S. (1996). Likelihood-Based Inference in Co-integrated Vector Autoregressive Models, $2^{\text {nd }}$ edition, Oxford University Press.

28. Johnson, A. (2006). The effects of FDI inflows on Host Country Economic Growth, CESIS Electronic Paper Series No-58

29. Juselius, Katarina. (2006). The Cointegrated VAR Model, Oxford University Press.

30. Kaminsky, G., \& Reinhart, C. (1999). The Twin Crises: The causes of Banking and Balance of Payments Problems, American Economic Reviews, 89,473-500

31. Laeven, L., \&Valencia, F. (2010). Resolution of Banking Crises: The Good, the Bad, and the Ugly, IMF Working Paper, 10/146

32. Laeven, Luc., \& Valencia, Fabian. (2013). Systematic Banking Crises Database.IMF Economic Review, 61(2).

33. Li, X., \&Liu, X. (2005). Foreign Direct Investment and Economic growth: An increasingly endogenous relationship. World Development,33(3),393-407.

34. Luiz R.de Mello, Jr. (1999). Foreign Direct Investment -led growth: Evidence from time series and panel data. Oxford Economic Papers 51,133-151

35. Maddison, A. (2007). The World Economy. Academic Foundation (OECD).

36. Mwega, Francis M. (2009). Global Financial Crisis. Discussion Series. Paper 7, Kenya. Overseas Development Institute.

37. Nachane, Dilip M. (2006). Econometrics: Theoretical Foundation and Empirical Perspectives. Oxford University Press.

38. Nair, Aishwarya. (2010, November). The relationship between FDI and economic growth: A case study of India from 1970-2007.Social Science Research Network Working paper.

39. N'guessan, Bi Zambe Serge Constant., \& Yaoxing, Yue. (2010, July). The relationship between foreign direct investment, trade openness and growth in Cote d'Ivoire. International Journal of Business and Management, 5(7).

40. Obstfeld, Maurice, \& Taylor, Alan M. (2002). Globalisation and Capital Markets, NBER Working Paper 8846 . 
41. Ragimena, Elizabeth Verseye. (2012). Foreign Direct Investment and Economic Growth in small island economies: The case of Solomon Islands. PhD thesis. Massey University, NewZealand.

42. Ray, Sarbapriya. (2012). Impact of FDI on economic growth in India: A Cointegration Analysis. Advances in Information Technology and Management, 2(1), 187-201.

43. Ray, Sarbapriya. (2012). Impact of FDI on economic growth in India: A Cointegration Analysis. Advances in Information Technology and Management, 2(1), 187-201.

44. Saji, T. G. (2013). Does Foreign Direct Investment Lead Economic Growth in India? International Journal of Financial Management, 3(2), 38-45.

45. Stehrer, R., \& Woerz, J. (2009). Attract FDI'!-A universal golden rule? Empirical evidence for OECD and selected non-OECD countries. European Journal of Development Research, 21(1), 95-111.

46. Tintin, Cem. (2012). Does Foreign Direct Investment Spur Economic Growth and Development? A comparative Study. Institute for European Studies, Brussels.

47. Tiwari, Aviral Kumar., \& Mihari, Muttascu. (2011, September). Economic growth and FDI in Asia: A panel Data Approach. Economic Analysis and Policy,41(2).

48. Twomey, Michael J. (1998, June). Patterns of foreign investment in the third world in the twentieth century. University of Michigan.

49. Twomey, Michael J. (2002). Century of Foreign Investment in the third world. Routledge.

50. Yesuf, M. Awel., \&Tsehaye, Weldegiorgis. (2012). FDI-Growth Nexus in Ethiopia: Is there any Causality? Maastricht University and Mekelle University.

51. Wilkins, Mira. (2005). The history of foreign investment in the United States-1914-1945, Harvard University Press.

52. World Development Report-2013

53. World Investment Report-2001

54. www.unctad.org 